\title{
SENYAWA ANTIOKSIDAN EKSTRAK ETANOL DAUN KELOR (MORINGA OLEIFERA) DI DENPASAR SELATAN BALI
}

\section{ANTIOXIDANT COMPOUNDS ETHANOL EXTRACT OF KELOR LEAVES (MORINGA OLEIFERA) IN DENPASAR SELATAN BALI}

\author{
Luh Putu Widiastini ${ }^{1}$, I G.Agung Manik Karuniadi ${ }^{2}$, Made Tangkas ${ }^{3}$ \\ Kebidanan, STIKES Bina Usada Bali \\ ^E-mail : enick.dilaga@gmail.com
}

\begin{abstract}
ABSTRAK
Tingginya kandungan gizi dan antioksidan dalam tanaman kelor menyebabkan kelor dikenal sebagai miracle of tree. Antioksidan dalam daun kelor berfungsi untuk mencegah radikal bebas baru, melindungi sel-sel dalam tubuh akibat serangan radikal bebas, sehingga tidak terjadi kerusakan yang lebih besar serta memperbaiki sel-sel dan jaringan yang rusak yang dapat berakibat pada stress oksidatif. Stress oksidatif dapat mengakibatkan gangguan psikologis seperti gangguan kecemasan, stress, depresi, skizoprenia hingga bipolar, pada kasus kebidanan dapat menyebabkan komplikasi pada reproduksi termasuk infertilitas, gangguan menstruasi, endometriosis, keguguran, pre eklampsia, hambatan pertumbuhan janin, persalinan premature, KPD, hingga dapat menimbulkan penyakit pada periode neonatal. Oleh karena itu, pada penelitian ini dilakukan pengujian fitokimia kadar Antioksidan dalam daun kelor. Hasil penelitian ini menyatakan bahwa kandungan daun kelor di daerah Denpasar Selatan Bali memiliki kapasitas antioksidan, antara lain kandungan Fenolat, Flavonoid, Tanin, Vitamin C, Alkaloid dan Saponin.
\end{abstract}

Kata Kunci : Daun Kelor (Moringa Oleifera), Fitokimia, Antioksidan

\section{ABSTRACT}

The high content of nutrients and antioxidants in the moringa plant causes moringa to be known as the miracle of tree. The antioxidants in Moringa leaves function to prevent new free radicals, protect cells in the body from free radical attack, so there is no greater damage and repair damaged cells and tissues that can result in oxidative stress. Oxidative stress can cause psychological disorders such as anxiety disorders, stress, depression, schizophrenia to bipolar disorder, in obstetric cases it can cause complications in reproduction including infertility, menstrual disorders, endometriosis, miscarriage, pre-eclampsia, fetal growth restriction, premature labor, PROM, and can cause disease. in the neonatal period. Therefore, in this study, phytochemical testing of antioxidant levels in Moringa leaves was carried out. The results of this study indicate that the content of Moringa leaves in the South Denpasar area of Bali has antioxidant capacity, including the content of Phenolates, Flavonoids, Tannins, Vitamin C, Alkaloids and Saponins.

Keyword : Moringa oleifera, Phytochemicals, antioxidant.

\section{PENDAHULUAN}

Moringa oleifera atau yang biasa dikenal tanaman kelor merupakan tanaman asli India (Gopalakrishnan, Doriya, and Kumar 2016), yang menyebar di banyak bagian dunia seperti Bangladesh, Afganistan, Afrika, Srilanka, Amerika, Brasil, Paraguay, Meksiko hingga Indonesia (Ferreira et al. 2008). Tingginya kandungan gizi dan antioksidan dalam tanaman kelor menyebabkan kelor dikenal sebagai miracle of tree (Phattarapong 2015).

Tubuh membutuhkan antioksidan yang berfungsi untuk mencegah radikal bebas baru, melindungi sel-sel dalam tubuh akibat serangan radikal bebas, menangkal radikal bebas serta mencegah terjadinya reaksi berantai sehingga tidak terjadi kerusakan yang lebih besar serta memperbaiki sel-sel dan jaringan yang rusak karena serangan radikal bebas (Razis, Ibrahim, and Kntayya 2014).
Radikal bebas adalah molekul, atom atau gugus yang memiliki 1 atau lebih elektron yang tidak berpasangan pada kulit terluarnya sehingga sangat reaktif dan radikal seperti radikal bebas turunan oksigen reaktif (Reactive Oxygen Species atau ROS). ROS terbentuk didalam tubuh, sebagai hasil dari metabolisme sel normal (ROS Endogen) dan sebagian kecil merupakan hasil paparan dari luar tubuh (ROS eksogen) yaitu oksigen reaktif yang berasal dari polutan lingkungan, radiasi, infeksi bakteri, jamur dan virus (Meilina 2009; Parwata 2015; Sanz and Stefanatos 2008).

$\begin{array}{crr}\text { Stress oksidatif merupakan } \\ \text { ketidakseimbangan antara } & \text { produksi }\end{array}$ Reactive oxygen species (ROS) dan mekanisme pertahanan antioksidan dalam tubuh yang dapat berakibat kerusakan oksidatif, penurunan fungsi seluler, penuaan dini (Luceri et al. 2018; Salmon et 
al. 2010). Stress oksidatif dapat mengakibatkan gangguan psikologis antara lain gangguan kecemasan, stress, depresi, skizoprenia hingga bipolar (Winnie 2020), sedangkan pada kasus kebidanan dapat menyebabkan komplikasi pada reproduksi termasuk infertilitas, gangguan menstruasi, endometriosis, keguguran, pre eklampsia, hambatan pertumbuhan janin, persalinan premature, KPD, hingga dapat menimbulkan penyakit pada periode neonatal (Díaz-Castro et al. 2015; Duhig, Chappell, and Shennan 2016). Antioksidan yang terdapat di dalam daun kelor bekerja menetralkan radikal bebas sehingga mencegah kerusakan oksidatif pada sebagian besar biomolekul dan menghasilkan proteksi terhadap kerusakan oksidatif secara signifikan (Sreelatha and Padma 2011).

Untuk mengetahui nilai kandungan antioksidan dalam daun kelor, perlu dilakukan uji fitokimia, agar penggunaannya optimal. Dari beberapa hasil penelitian tentang kandungan fitokimia daun kelor diperoleh bahwa, daun kelor memiliki kandungan alkaloid, flavonoid, saponin, triterpenoid/steroid, tannin serta nilai IC50 $4.33 \mathrm{mg} / \mathrm{mL}$ (Cahyani dan Sukadana, 2017), Quinon (Wasonowati et al. 2019). Namun perlu diperhatikan, bahwa kondisi geografis tiap daerah berbeda hal ini dapat berdampak pada perbedaan kandungan senyawa kimia yang terdapat pada daun kelor. Oleh karena itu peneliti tertarik melakukan uji fitokimia ekstrak etanol daun kelor di daerah Denpasar Selatan Bali.

\section{METODE \\ Tempat}

Penelitian ini dilakukan di Laboratorium Analisis Pangan, Fakultas Pertanian Universitas Udayana Bali.

\footnotetext{
Alat dan Bahan

Alat yang digunakan dalam penelitian ini adalah gelas ukur, gelas beker, blender, tabung reaksi, neraca analitik, aluminium voil, lampu spritus, penguap vakum putar (rotary vapour), alat pemanas air, kertas saring, batang pengaduk, spatula, pipet tetes. Bahan yang digunakan daun kelor (moringa oleifera), etanol 96\%, Asam sulfat, sodium fosfat, ammonium molibdad, aquades, $\mathrm{HCl}$, reagen folin, $\mathrm{Na} 2 \mathrm{CO} 35 \%$, Metanol $100 \%$, NaNO2 5\%, $\mathrm{NaOH}$, reagen Folin-Denis, $\mathrm{Na} 2 \mathrm{CO} 30.5 \%$, $\mathrm{HCL} 1 \%$, reagen Dragendorff, reagen Mayer.
}

\section{Cara Kerja}

Ekstraksi Daun Kelor

Ekstrak daun kelor dibuat dengan maserasi sebanyak 50 gram daun kelor kering, dihancurkan menggunakan blender, ditambahkan pelarut etanol 96\%, dimasukkan ke dalam wadah, ditutup dan dibiarkan selama dua hari terlindung dari sinar matahari. Campuran ini disaring sehingga didapat maserat. Ampas dimaserasi dengan etanol $96 \%$ menggunakan prosedur yang sama. Maserasi dilakukan sampai diperoleh maserat yang yang jernih. Maserat diuapkan dengan menggunakan alat penguap vakum putar (vacuum rotary evaporator) pada suhu $40^{\circ} \mathrm{C}$.

\section{Uji Fitokimia \\ Uji Aktivitas Fenol}

Sample sebanyak $10 \mathrm{mg}$ dilarutkan dalam volume tertentu dengan methanol $85 \%$ kemudian divortex, saring, filtrat, standard an filtrate dipipet $0.4 \mathrm{ml}+$ reagen folin $0.4 \mathrm{ml}$ (vortex), diamkan 6 menit, ditambahkan Na2CO3 5\% sebanyak $4.2 \mathrm{ml}$ sehingga total larutan menjadi $5 \mathrm{ml}$, vortex, diamkan 30 menit, baca hasil absorbansi pada $760 \mathrm{~nm}$.

\section{Uji Aktivitas flavonoid}

Sampel sebanyak $10 \mathrm{mg}$ dilarutkan dalam volume tertentu dengan methanol $100 \%$, diambil 20 ul, ditambahkan $2.5 \mathrm{ml}$ aquadest, ditambah 0.15 uL NaNO2 5\%, vortex dan diamkan selama 5 menit, ditambah $\mathrm{AICl} 35 \%$ sebanyak $0.3 \mathrm{uL}$, diamkan selama 5 menit, ditambahkan $1 \mathrm{ml}$ $\mathrm{NaOH} 1 \mathrm{~N}$, ditambahkan aquades hingga 5 $\mathrm{ml}$, vortex hingga homogeny, inkubasi selama 30 menit, baca absorbansi pada $510 \mathrm{~nm}$.

\section{Uji Aktivitas Tanin}

Sebanyak $0.1 \mathrm{ml}$ sampel dilarutkan dengan $0.5 \mathrm{ml}$ reagen Folin-Denis, kemudian ditambahkan $1 \mathrm{ml}$ larutan $\mathrm{Na} 2 \mathrm{CO} 30.5 \%$ dan ditambahkan aquades (sampai volume keseluruhan $10 \mathrm{ml}$ ), larutan di vortex kemudian didiamkan selama 30 menit, absorbansi diukur menggunakan spektrofotometer pada panjang gelombang $755 \mathrm{~nm}$.

Uji Aktivitas Vitamin C

1-2 gr sampel ditambahkan aquades 5$10 \mathrm{ml}$, vortex kemudian disaring, filtrate, pipet filtrate sebanyak $0.3 \mathrm{ml}(300 \mathrm{uL})$ 
ditambahkan reagen sebanyak $3 \mathrm{ml}$, vortex hingga homogen, diinkubasi dalam waterbath suhu $95{ }^{\circ} \mathrm{C}$ selama 90 menit, dinginkan, kemudian baca absorbansi pada $695 \mathrm{~nm}$.

\section{Uji Aktivitas Saponin}

Sampel sebanyak 2,5 mL ditambahkan beberapa tetes akuades kemudian dikocok dengan kencang (hasil uji positif ditandai dengan timbulnya buih/busa yang bertahan lebih dari 30 detik).

\section{Uji Aktivitas Alkaloid}

Sampel sebanyak $3 \mathrm{~mL}$ ditambahkan dengan $3 \mathrm{~mL} \mathrm{HCl} 1 \%$, kemudian dipanaskan sambil diaduk sekitar 10 menit. Setelah itu dipipet sebanyak $1 \mathrm{~mL}$ ke dalam 2 tabung berbeda. Tabung I ditambahkan beberapa tetes reagen Dragendorff (hasil uji positif ditandai dengan timbulnya endapan berwarna jingga). Tabung II ditambahkan beberapa tetes reagen Mayer (hasil uji positif ditandai dengan timbulnya endapan berwarna krim kekuningan).

Uji Kapasitas Antioksidan

$25 \mathrm{mg}$ sampel kering (bubuk) diencerkan menggunakan $10 \mathrm{ml}$ Metanol $100 \%$ di vortex, sentrifuge $3000 \mathrm{rpm}$ selama 15 menit, di saring, filtrate di pipet $0.5 \mathrm{ml}$, ditambahkan $3.5 \mathrm{ml} \mathrm{DPPH}$, divortex, diamkan selama 30 menit, baca absorbansi pada $517 \mathrm{~nm}$.

\section{HASIL DAN PEMBAHASAN Hasil}

Tabel 1

Hasil Uji Fitokimia Ekstrak Etanol Daun Kelor (Moringa Oleifera) daerah Denpasar Selatan, Bali

\begin{tabular}{llll}
\hline No & Uji Fitokimia & Sample & Hasil \\
\hline 1 & Fenolat & $\mathrm{mg} / 100 \mathrm{~g}$ & 1556.52 \\
\hline 2 & Flavonoid & $\mathrm{mg} / 100 \mathrm{~g}$ & 23546.12 \\
\hline 3 & Tanin & $\mathrm{mg} / 100 \mathrm{~g}$ & 1300.34 \\
\hline 4 & Vit C & $\mathrm{mg} / 100 \mathrm{ml}$ & 23798.077 \\
\hline 5 & Saponin & $\mathrm{mg} / 100 \mathrm{ml}$ & Positif $(+)$ \\
\hline 6 & Alkaloid & $\mathrm{mg} / 100 \mathrm{ml}$ & Positif $(+)$ \\
\hline 7 & Kapasitas & $\mathrm{mg} / \mathrm{L}$ & 1812.95 \\
& Antioksidan & GAEAC & \\
\hline
\end{tabular}

Dari table 1 diperoleh data bahwa kandungan ekstrak etanol daun kelor di daerah Denpasar Selatan Bali mengandung Fenolat, Flavonoid, Tanin, Vitamin C, Saponin, Alkaloid dan serta memiliki Kapasitas Antioksidan

\section{Pembahasan}

Antioksidan yang terdapat di dalam daun kelor bekerja menetralkan radikal bebas sehingga mencegah kerusakan oksidatif pada sebagian besar biomolekul dan menghasilkan proteksi terhadap kerusakan oksidatif secara signifikan (Sreelatha and Padma 2011)

1. Fenolat

Fenolat adalah salah satu jenis senyawa polifenol yang terkandung secara alami dalam tumbuhan. Senyawa ini bereaksi dengan mengurai radikal peroksida (ROO*) (Adedapo et al. 2008) dan radikal hidroksi $\left(\mathrm{HO}^{*}\right)$, transfer atom hidrogen, transfer elektron tunggal, transfer elektron kehilangan proton sekuensial, dan chelation logam transisi sehingga menghasilkan reaksi fenoksi yang lebih stabil (Lim, Lim, and Tee 2007; Zeb 2020).

\section{Flavonoid}

Flavonoid adalah antioksidan eksogen yang telah dibuktikan bermanfaat dalam mencegah kerusakan sel akibat stres oksidatif. Mekanisme kerja dari flavonoid sebagai antioksidan bisa secara langsung maupun secara tidak langsung. Flavonoid sebagai antioksidan secara langsung adalah dengan mendonorkan ion hidrogen sehingga dapat menetralisir efek toksik dari radikal bebas (Akhlaghi and Bandy 2009). Berdasarkan penelitian yang dilakukan oleh Lestari (2018), Daun kelor mengandung flavonoid yang dapat menghambat $N F k \beta$ sehingga dapat menekan jumlah apoptosis sel granulosa pada mencit model endometriosis

3. Tannin

Tannin yang berfungsi sebagai antioksidan, senyawa tannin tersusun dari senyawa polifenol yang memiliki aktivitas penangkal radikal bebas (Hagerman 2011).

4. Vitamin C

Vitamin C atau asam askorbat dalah salah satu vitamin yang larut dalam air. Vitamin $\mathrm{C}$ berperan dalam reaksi kimia dalam tubuh sebagai pembawa elektron. Beberapa penelitian menunjukkan bahwa vitamin $\mathrm{C}$ memiliki peran penting dalam mencegah kerusakan DNA. Pada penelitian yang dilakukan oleh Green et al., (1994), menunjukkan bahwa asupan vitamin C 
secara signifikan mengurangi kerusakan DNA, selain itu Kandungan vitamin $C$ dalam daun kelor membantu penyerapan zat besi dalam tubuh (Handayani and Arifin 2017)

5. Saponin

Senyawa saponin mempunyai efek antioksidan dengan membentuk hidroperoksida sebagai antioksidan sekunder sehingga menghambat pembentukan lipid peroksida (Akhlaghi and Bandy 2009).

6. Alkaloid

Mekanisme alkaloid sebagai antioksidan adalah dengan cara mendonorkan atom $\mathrm{H}$ pada radikal bebas. Sehingga menunjukkan bahwa alkaloid sebagai antioksidan primer (Chung and Shin 2007; Yuan et al. 2012).

Hal ini sejalan dengan penelitian yang dilakukan dengan menggunakan sampel daun kelor yang diambil di kawasan Denpasar Utara, Bali, diketahui bahwa ekstrak etanol daun kelor (Moringa oleifera L.) mengandung senyawa alkaloid, flavonoid, saponin, triterpenoid/steroid dan tannin (Putra et al., 2017), sample yang digunakan dari Ende menunjukkan bahwa ekstrak etanol daun kelor mengandung senyawa flavonoid, Fenolat, triterpenoid, steroid, dan tanin. Kemampuan antioksidan menangkap radikal bebas DPPH dengan nilai IC50 $4.33 \mathrm{mg} / \mathrm{mL}$ (Cahyani dan Sukadana, 2017), serta analisis fitokimia ekstrak daun kelor yang dilakukan di Madura memperoleh hasil bahwa komponen yang ditemukan dalam ekstrak adalah alkaloid, triterpenoid, steroid, saponin dan quinon. Ekstrak daun kelor dengan tangkai daun dan lokasi tanam yang berbeda mengandung alkaloid, triterpenoid, steroid, saponin dan quinon yang dapat dimanfaatkan sebagai antioksidan dan bahan herbal (Wasonowati et al. 2019).

\section{KESIMPULAN}

Hasil penelitian ini dapat disimpulkan bahwa daun kelor (Moringa Oleifera) yang terdapat di Denpasar Selatan Bali mengandung kapasitas antioksidan antara lain Fenolat, Flavonoid, Tanin, Vitamin C, Saponin serta Alkaloid.
DAFTAR PUSTAKA

Adedapo, Adeolo A. et al. 2008. "Antibacterial and Antioxidant Properties of the Methanol Extracts of the Leaves and Stems of Calpurnia Aurea." BMC Complementary and Alternative Medicine 8: 1-8.

Akhlaghi, Masoumeh, and Brian Bandy. 2009. "Mechanisms of Flavonoid Protection against Myocardial Ischemia-Reperfusion Injury." Journal of Molecular and Cellular Cardiology 46(3): $\quad$ 309-17. http://dx.doi.org/10.1016/j.yjmcc.2008. 12.003.

Cahyani, Sisilia Leny, and I Made Sukadana. 2017. "Skrining Fitokimia Dan Aktivitas Penangkapan Radikal Bebas DPPH Ekstrak Etanol Daun Kelor (Moringa Oleifera) Di Ende." jurnal poltekkes kupang: 410-16.

Chung, Ha Sook, and Jin Chul Shin. 2007. "Characterization of Antioxidant Alkaloids and Phenolic Acids from Anthocyanin-Pigmented Rice (Oryza Sativa Cv. Heugjinjubyeo)." Food Chemistry 104(4): 1670-77.

Díaz-Castro, Javier et al. 2015. "A New Approach to Oxidative Stress and Inflammatory Signaling during Labour in Healthy Mothers and Neonates." Oxidative Medicine and Cellular Longevity 2015.

Duhig, Kate, Lucy C. Chappell, and Andrew H. Shennan. 2016. "Oxidative Stress in Pregnancy and Reproduction." Obstetric Medicine 9(3): 113-16.

Ferreira, Paulo Michel Pinheiro, Davi Felipe Farias, José Tadeu De Abreu Oliveira, and Ana De Fátima Urano Carvalho. 2008. "Moringa Oleifera: Bioactive Compounds and Nutritional Potential." Revista de Nutricao 21(4): 431-37.

Gopalakrishnan, Lakshmipriya, Kruthi Doriya, and Devarai Santhosh Kumar. 2016. "Moringa Oleifera: A Review on Nutritive Importance and Its Medicinal Application." Food Science and Human Wellness 5(2): 49-56. http://dx.doi.org/10.1016/j.fshw.2016.0 4.001.

Green, Michael H.L. et al. 1994. "Effect of Diet and Vitamin C on DNA Strand Breakage in Freshly-Isolated Human White Blood Cells." Mutation Research DNAging 316(2): 91-102. 
Hagerman, Ann E. 2011. Department of Chemistry and Biochemistry The Tannin Handbook. Miami: Miami University.

Handayani, Sri, and Zaenal Arifin. 2017. "PENGARUH DAUN KELOR (Moringa Oleifera) TERHADAP PENINGKATAN KADAR HEMOGLOBIN PADA WANITA USIA REPRODUKTIF YANG MENGALAMI ANEMIA." Prosiding Seminar Nasional Kebidanan dan Call for Paper.

Lestari, Yusri Dwi. 2018. "Pengaruh Ekstrak Etanol Daun Kelor (Moringa Oleifera Lam.) Terhadap Apoptosis Sel Granulosa Pada Mencit (Mus Musculus) Model Endometriosis." Jurnal Biosains Pascasarjana 20(1): 1.

Lim, Y. Y., T. T. Lim, and J. J. Tee. 2007. "Antioxidant Properties of Several Tropical Fruits: A Comparative Study." Food Chemistry 103(3): 1003-8.

Luceri, Cristina et al. 2018. "Aging Related Changes in Circulating Reactive Oxygen Species (ROS) and Protein Carbonyls Are Indicative of Liver Oxidative Injury." Toxicology Reports 5(November 2017): 141-45. https://doi.org/10.1016/j.toxrep.2017.1 2.017.

Meilina. 2009. "Peranan Antioksidan Pada Lanjut Usia." In Kepaniteraan Klinik Gerontologi Medik, Cibubur: Fakultas Kedokteran Universitas Tarumanagara, 718-35.

Parwata, Oka Adi. 2015. Uji Bioaktivitas: Antioksidan. Denpasar: Universitas Udayana.

Phattarapong, T. 2015. Moringa a Superfood.

Putra, Dwika Pratama, Oka Dharmayudha, and Sudimartini. 2017. "Identifikasi Senyawa Kimia Ekstrak Etanol Daun Kelor (Moringa Oleifera L) Di Bali."
Indonesia Medicus Veterinus 5(5): 464-73.

Razis, Ahmad Faizal Abdull, Muhammad Din Ibrahim, and Saie Brindha Kntayya. 2014. "Health Benefits of Moringa Oleifera." Asian Pacific journal of cancer prevention (APJCP) 15(20): 8571-76.

Salmon, Adam B, Arlan Richardson, Viviana I Pérez, and Author Manuscript. 2010. "Update on the Oxidative Stress Theory of Aging: Does Oxidative Stress Play a Role in Aging or Healthy Aging?" Free Radic Biol Med 11(5): 386-92.

Sanz, Alberto, and Rhoda K.A. Stefanatos. 2008. "The Mitochondrial Free Radical Theory of Aging." Current Aging Science 1(1): 10-27.

Sreelatha, S., and P. R. Padma. 2011. "Modulatory Effects of Moringa Oleifera Extracts against Hydrogen Peroxide-Induced Cytotoxicity and Oxidative Damage." Human and Experimental Toxicology 30(9): 135968.

Wasonowati, Catur, Endang Sulistyaningsih, Didik Indradewa, and Budiastuti Kurniasih. 2019. "Analisis Fitokimia Ekstrak Daun Kelor ( Moringa OleiferaLamk ) Di Madura." Prosiding SEMNASDAL (Seminar Nasional Sumber daya Lokal) 2(9): 421-27.

Winnie. 2020. "Stres Oksidatif Bukan Cuma Pikiran, Tubuh Juga Bisa Stres!" https://riliv.co/.

Yuan, Jingsong et al. 2012. "Alkaloids from Areca (Betel) Nuts and Their Effects on Human Sperm Motility In Vitro." Journal of Food Science 77(4): 70-78.

Zeb, Alam. 2020. "Concept, Mechanism, and Applications of Phenolic Antioxidants in Foods." Journal of Food Biochemistry 44(9): 1-22. 